\title{
Evaluation of economic viability and sensitivity analysis of Indian major carp culture
}

\author{
NARAYAN BAG ${ }^{1}$, SANJIB MOULICK ${ }^{2}$ AND BIMAL CHANDRA MAL ${ }^{3}$ \\ ${ }^{1}$ Fishery Extension Officer, Uluberia-I Dev. Block, Uluberia R.S. P.O., Howrah - 711 316, West Bengal, India \\ ${ }^{2}$ School of Civil Engineering, KIIT University, Bhubaneswar - 751 024, Odisha, India \\ ${ }^{3}$ Swami Vivekananda Technical University, Bhilai - 490 009, Chhattisgarh, India \\ e-mail:ns8nov2003@yahoo.co.in
}

\begin{abstract}
Indian major carps viz., catla Catla catla (Hamilton); rohu Labeo rohita (Hamilton) and mrigal Cirrhinus mrigala (Hamilton) were cultured with a stocking density of 50000 fingerlings ha $^{-1}$ for a period of 300 days with all possible best management practices. Sensitivity of different fixed and operating cost variables, production and sale price involved in the experiment were analysed. All the above costs varied by $\pm 10 \%, \pm 20 \%$ and $\pm 30 \%$ respectively and the net present value (NPV) and internal rate of return (IRR) were determined. Among all the inputs, feed cost was found to be the most sensitive. NPV and IRR values ranged from 7 to $20 \%$ and 5 to $15 \%$ respectively with varied feed cost ranging from 10 to $30 \%$. Increases either in the production or in the sale price by 10,20 and 30\%, led to increase in the NPV by around 22,43 and $65 \%$ and IRR by around 17, 33 and $49 \%$ respectively from their original values. Present study suggests that proper feeding and marketing strategy should be emphasised to get maximum economic benefit from Indian major carp culture.
\end{abstract}

Keywords: Fixed cost variables, Indian major carps, Internal rate of return, Net present value, Operating cost variables, Sensitivity

\section{Introduction}

Demand of fishery products is increasing worldwide to meet the nutritional requirements of the increasing human population (Banas et al., 2007). As the natural supply of fishes both from marine and freshwater sources has reached sustainable limit, aquaculture is the only way of increasing world supply of fishery products (Boyd, 2003; Sugiura et al., 2006; Banas et al., 2007). In India, aquaculture is almost synonymous to carp culture since carps contribute to more than $80 \%$ of the total aquaculture production of country (Jena and Das, 2006).

The Indian major carps viz., catla Catla catla (Hamilton); rohu Labeo rohita (Hamilton) and mrigal, Cirrhinus mrigala (Hamilton) are the dominant species in freshwater aquaculture in India (Nandeesha et al., 2001; Biswas et al., 2006) contributing more than $82 \%$ of the total inland aquaculture production (FAO, 2003). Though large numbers of literature are available on carp culture with the stocking densities varying from 690 to 35,000 fingerlings $\mathrm{ha}^{-1}$ with recorded production levels ranging from 600 to $25000 \mathrm{~kg} \mathrm{ha}^{-1}$ year $^{-1}$ in different culture systems (Alikunhi et al., 1971; Lakshmanan et al., 1971; Das et al., 1975, 1977, 1980; Chaudhuri et al., 1974, 1975, 1978; Chakrabarty et al., 1979a,b; Jhingran, 1991; CIFA, 1998; Tripathi et al., 2000; Jena et al., 2002a,b; Reddy et al., 2002), the most important aspect of economic analysis has generally been ignored in these studies. Moreover, the sensitivity of different fixed as well as operating cost variables involved in a carp culture system has not been studied earlier. In the present study, different economic parameters like capital expenditure, input costs, income, profit, net present value (NPV) and internal rate of return (IRR) were calculated and the sensitivity analysis of different variables involved in Indian major carp production system was carried out.

\section{Materials and methods}

\section{Study area and experimental design}

The field experiment was conducted from 20 June 2008 to 16 April 2009 for a period of 300 days at the aquaculture farm of the Agricultural and Food Engineering Department, Indian Institute of Technology, Kharagpur, India. Three numbers of polythene (Silpauline, $150 \mathrm{~g} \mathrm{~m}^{-2}$ in weight, $250 \mu \mathrm{m}$ thick, UV ray protected, blue in colour) lined ponds of average water area 0.015 ha and water depth $1.2 \mathrm{~m}$ were used for the experiment to avoid high seepage loss of the project site. Loamy soil was provided over the lining at the pond bed to a thickness of about $30 \mathrm{~cm}$ to simulate natural pond environment. The ponds were stocked with fingerlings of catla 
$(16.78 \pm 1.84 \mathrm{~g}), \quad$ rohu $(16.82 \pm 1.69 \mathrm{~g})$ and mrigal $(16.65 \pm 1.83 \mathrm{~g})$ at a stocking density of 50000 fingerlings ha $^{-1}$ with a species combination of catla $40 \%$, rohu $30 \%$ and mrigal $30 \%$. Pelleted feed containing 35\% crude protein prepared at the Aquacultural Engineering Processing Laboratory was fed to the fishes. The $\mathrm{pH}$ of water was maintained within its ideal range (6.5 -9.0) through intermittent application of agricultural lime. The concentration of major influencing inorganic water quality parameters particularly the total ammonia nitrogen (TAN) was maintained within the acceptable range through water exchange. The experiment was conducted within an integrated aquaculture and irrigation system (IAI) where the pond effluent was used as a source of enriched water for irrigation as it contained inorganic nutrients which were useful to the agricultural crops. So, no expenditure was considered for the purpose of water exchange. Supplementary aeration was provided to maintain dissolved oxygen concentration of the pond water above $4 \mathrm{mg} \mathrm{l}^{-1}$.

\section{Economic analysis techniques}

The field trials were conducted using ponds of 0.015 ha area each. To analyse the economic benefit of the experiment, one hectare (ha) pond area was considered. The cost of various items was suitably scaled up for 1ha area based on the cost involved in 0.015 ha area. Considering the durability of the polythene lining and other machineries, the life time of the project (n) was assumed as 10 years. Depending on the recurring expenditure and income of the present study, cash flows (CF) for 10 years were decided considering a discount (k) rate of $10 \%$. Fixed cost variables of the system viz., soil excavation, polythene sheet, labour for miscellaneous works at the time of pond construction and aeration facility and the key operating cost variables viz., feed, fingerlings and electricity for aeration and finally, the fluctuations in sale price and the production were included in the sensitivity analysis. All the above costs varied by $\pm 10 \%, \pm 20 \%$ and $\pm 30 \%$ and the NPV and IRR were determined to enable a direct comparison.

Inputs, costs and income

A sum of ₹990700 was estimated to be invested as the capital expenditure (Table 1). The details of recurring costs for various items, the income by selling fish and the profit (cash flow) are presented in Table 2. A sum of ₹607964 was required as the recurring expenditure for

Table 1. Initial outlay for construction of 1 ha farm

\begin{tabular}{ll}
\hline Particulars & Expenditures $(₹)$ \\
\hline Soil excavation & 386100 \\
Polythene sheet & 353600 \\
Brick and sand & 86000 \\
Labour for different works & 40000 \\
Miscellaneous expenditure & 25000 \\
Aerators (4 paddle wheel aerators of & 100000 \\
$1.12 \mathrm{~kW})$ with accessories & \\
\hline Total & 990700 \\
\hline
\end{tabular}

$₹ 44.50=1.00 \$$ (Approximate)

Table 2. Cost and returns in 1 ha farm

\begin{tabular}{|c|c|c|}
\hline Particulars & Amount (₹) & $\%$ to total \\
\hline \multicolumn{3}{|l|}{ A. Investment costs } \\
\hline Lime & 3600 & 0.59 \\
\hline Cowdung & 1500 & 0.25 \\
\hline Urea & 180 & 0.03 \\
\hline SSP & 160 & 0.03 \\
\hline Fingerlings & 50000 & 8.22 \\
\hline Fish feed & 407733 & 67.06 \\
\hline Aeration cost & 74600 & 12.27 \\
\hline Netting & 8000 & 1.32 \\
\hline Prophylactics & 8000 & 1.32 \\
\hline Labour for monitoring, feeding, water exchange and aeration & 30000 & 4.93 \\
\hline Maintenance & 24191 & 3.98 \\
\hline Total input costs (₹ $\left.\mathrm{ha}^{-1} \mathrm{crop}^{-1}\right)$ & $607964 \pm 12708$ & 100.00 \\
\hline \multicolumn{3}{|l|}{ B. Income from different treatments } \\
\hline Total production $\left(\mathrm{kg} \mathrm{ha}^{-1} \mathrm{crop}^{-1}\right)$ & $14814 \pm 143$ & \\
\hline Sale price & $₹ 90 \mathrm{~kg}^{-1}$ & \\
\hline Total income (₹ ha $^{-1}$ crop $\left.^{-1}\right)$ & $1334224 \pm 11291$ & \\
\hline
\end{tabular}

SSP - single super phosphate; ₹44.50 = $1.00 \$$ (Approximate). Data are means ( \pm standard deviation) of three replicates 
the culture operation and ₹1334224 was recorded as the income by selling fish at @ ₹90 per kg.

\section{Calculation of net present value and internal rate of return}

Net present value (NPV) analysis applies the time value of money to cash inflows and outflows over the life of the project so that the management can evaluate the project's benefits and costs at one point in time (Larson et al., 2002). NPV is computed by discounting the future net cash inflows at the project's required rate of return, and then subtracting the initial amount invested (Larson et al., 2002). Hence, a positive NPV highlights that the present value of the net cash inflows to be received over the project's life exceeds the amount of the initial investment, and hence is an indicator of economic viability. The value of NPV was calculated using the following formula:

$$
\mathrm{NPV}=\sum_{\mathrm{t}=0}^{\mathrm{n}} \frac{\mathrm{CF}_{\mathrm{t}}}{(1+\mathrm{K})^{\mathrm{t}}}-\mathrm{IO}
$$

where, $\mathrm{CF}=$ cash flow over the life of the project; $\mathrm{IO}=$ initial outlay; $\mathrm{k}=$ discounted rate or cost of capital and $\mathrm{n}=$ life time of the project.

Internal rate of return (IRR) is the rate used to evaluate an investment's feasibility which reflects the rate of return the project earns (Petty et al., 1996; Larson et al., 2002). Mathematically, IRR is the discount rate that yields an NPV of zero for an investment (Larson et al., 2002). Hence, a project evaluated according to IRR is accepted if its IRR is greater than or equal to the required rate of return (Petty et al., 1996). A minimum discount rate of $10 \%$ was used in the present study. IRR was calculated by determining the value of discount rate at which NPV becomes zero.

$$
\mathrm{IO}=\sum_{\mathrm{t}=0}^{\mathrm{n}} \frac{\mathrm{CF}_{\mathrm{t}}}{(1+\mathrm{K})^{\mathrm{t}}}
$$

\section{Analysis of key variables affecting profitability}

Key operating cost variables viz., feed, fingerlings and electricity for aeration were identified as the main operating costs of the aquaculture system and subsequently were included in the sensitivity analysis. Fixed cost variables of the system viz., soil excavation, polythene sheet, labour and aeration facility and finally, the large fluctuations in production and sale price were also addressed. All the above costs were varied by $\pm 10 \%$, $\pm 20 \%$ and $\pm 30 \%$ and the NPV and IRR were determined to enable a direct comparison. The deviation (\%) in the values from its original was also estimated for comparison.

\section{Results and discussion}

The net present value (NPV) of ₹5612161 and the internal rate of return (IRR) of $82.86 \%$ were obtained in the present study. These figures of NPV and IRR clearly indicate that the project is highly acceptable from economic point of view. Among the different items in terms of capital as well as recurring inputs, production and sale price, it is important to identify the items affecting the economy of the project significantly. Special attention needs to be paid for economic utilisation of those items during the culture operation. The variations in the values of NPV and IRR with 10, 20 and 30\% increase or decrease in the cost of the items are presented in Tables 3, 4 and 5 respectively.

The percentage deviation in the values from its original was also estimated for comparison. It is seen from the tables that the labour charge for miscellaneous works during pond construction, cost of aeration facilities with accessories, cost of fingerlings and the cost of electricity for aeration are less sensitive since variations in costs of these items with their original values as high as 30\%, cause less than 5\% variations both in NPV and IRR.

It is also seen from the tables that a variation of $\pm 10 \%$ in the costs of soil excavation and polythene sheet is not sensitive either to NPV or to IRR. However, with variations of $\pm 20 \%$ and $\pm 30 \%$, they were found to be sensitive to IRR but not to NPV. The variation in the cost of capital expenditure as a whole is found to have more influence on IRR compared to NPV.

On the other hand, the input cost as a whole, is found to have very significant effect compared to capital expenditure, especially on the NPV and less on IRR. Among all the inputs, feed is found to be the most sensitive as it increases or decreases the NPV and IRR at a faster rate compared to any other inputs. The variations in NPV and IRR ranged from about 7 to $20 \%$ and 5 to $15 \%$ respectively for variations of feed cost in the range of 10 to $30 \%$. However, the production and the sale price of the fish are identified as the two most influential factors among all the items. As expected, variations either in production or in sale price influence the NPV and the IRR by the same degree. The increases either in the production or in the sale price by 10, 20 and 30\%, increase the NPV by about 22,43 and $65 \%$ respectively and IRR by about 17,33 and $49 \%$ respectively from their original values. Similar trends were also recorded by Ionno et al. (2006) in a recirculating aquaculture system (RAS).

Therefore, it is clear from the sensitivity analysis that special attention should be paid to the production cost of feed and its optimum utilisation. Also proper marketing strategy, such as, harvesting at lean period of supply and period of maximum demand as well as identification of good market should be followed to earn maximum profit. In the present study, the feed ingredients were 
Table 3 . Sensitivity analysis of different variables with $\pm 10 \%$ variation in cost

\begin{tabular}{|c|c|c|c|c|c|}
\hline \multirow{3}{*}{ Item } & \multirow[b]{2}{*}{ Particulars } & \multicolumn{4}{|c|}{ Economic parameter } \\
\hline & & $\begin{array}{l}\text { NPV (at 10\% } \\
\text { discount rate) (₹) }\end{array}$ & $\begin{array}{l}\% \text { Increase } \\
\text { or decrease }\end{array}$ & IRR (\%) & $\begin{array}{l}\% \text { Increase } \\
\text { or decrease }\end{array}$ \\
\hline & Original value & 5612161 & - & 82.86 & - \\
\hline Soil excavation & $\begin{array}{l}+10 \% \\
-10 \%\end{array}$ & $\begin{array}{l}5573554 \\
5650774\end{array}$ & $\begin{array}{l}-0.69 \\
+0.69\end{array}$ & $\begin{array}{l}80.05 \\
85.88\end{array}$ & $\begin{array}{l}-3.39 \\
+3.64\end{array}$ \\
\hline Polythene sheet & $\begin{array}{l}+10 \% \\
-10 \%\end{array}$ & $\begin{array}{l}5576804 \\
5647524\end{array}$ & $\begin{array}{l}-0.63 \\
+0.63\end{array}$ & $\begin{array}{l}80.28 \\
85.62\end{array}$ & $\begin{array}{l}-3.11 \\
+3.33\end{array}$ \\
\hline Labour charge & $\begin{array}{l}+10 \% \\
-10 \%\end{array}$ & $\begin{array}{l}5608164 \\
5616164\end{array}$ & $\begin{array}{l}-0.07 \\
+0.07\end{array}$ & $\begin{array}{l}82.56 \\
83.16\end{array}$ & $\begin{array}{l}-0.36 \\
+0.36\end{array}$ \\
\hline $\begin{array}{l}\text { Aeration facility } \\
\text { with accessories }\end{array}$ & $\begin{array}{l}+10 \% \\
-10 \%\end{array}$ & $\begin{array}{l}5602164 \\
5622164\end{array}$ & $\begin{array}{l}-0.18 \\
+0.18\end{array}$ & $\begin{array}{l}82.11 \\
83.62\end{array}$ & $\begin{array}{l}-0.90 \\
+0.92\end{array}$ \\
\hline Capital investment & $\begin{array}{l}+10 \% \\
-10 \%\end{array}$ & $\begin{array}{l}5513094 \\
5711234\end{array}$ & $\begin{array}{l}-1.76 \\
+1.76\end{array}$ & $\begin{array}{l}76.04 \\
91.13\end{array}$ & $\begin{array}{l}-8.23 \\
+9.98\end{array}$ \\
\hline Fingerlings & $\begin{array}{l}+10 \% \\
-10 \%\end{array}$ & $\begin{array}{l}5566706 \\
5657622\end{array}$ & $\begin{array}{l}-0.81 \\
+0.81\end{array}$ & $\begin{array}{l}82.34 \\
83.37\end{array}$ & $\begin{array}{l}-0.63 \\
+0.61\end{array}$ \\
\hline Feed cost & $\begin{array}{l}+10 \% \\
-10 \%\end{array}$ & $\begin{array}{l}5241469 \\
5982859\end{array}$ & $\begin{array}{l}-6.60 \\
+6.60\end{array}$ & $\begin{array}{l}78.65 \\
87.04\end{array}$ & $\begin{array}{l}-5.36 \\
+5.04\end{array}$ \\
\hline Electricity for aeration & $\begin{array}{l}+10 \% \\
-10 \%\end{array}$ & $\begin{array}{l}5544341 \\
5679987\end{array}$ & $\begin{array}{l}-1.21 \\
+1.21\end{array}$ & $\begin{array}{l}82.09 \\
83.62\end{array}$ & $\begin{array}{l}-0.93 \\
+0.92\end{array}$ \\
\hline Input cost & $\begin{array}{l}+10 \% \\
-10 \%\end{array}$ & $\begin{array}{l}5059428 \\
6164901\end{array}$ & $\begin{array}{l}-9.85 \\
+9.85\end{array}$ & $\begin{array}{l}76.58 \\
89.09\end{array}$ & $\begin{array}{l}-7.58 \\
+7.52\end{array}$ \\
\hline Production & $\begin{array}{l}+10 \% \\
-10 \%\end{array}$ & $\begin{array}{l}6825187 \\
4399141\end{array}$ & $\begin{array}{l}+21.61 \\
-21.61\end{array}$ & $\begin{array}{l}96.51 \\
69.03\end{array}$ & $\begin{array}{l}+16.47 \\
-16.69\end{array}$ \\
\hline Sale price & $\begin{array}{l}+10 \% \\
-10 \%\end{array}$ & $\begin{array}{l}6825187 \\
4399141\end{array}$ & $\begin{array}{l}+21.61 \\
-21.61\end{array}$ & $\begin{array}{l}96.51 \\
69.03\end{array}$ & $\begin{array}{l}+16.47 \\
-16.69\end{array}$ \\
\hline
\end{tabular}

Table 4 . Sensitivity analysis of different variables with $\pm 20 \%$ variation in cost

\begin{tabular}{|c|c|c|c|c|c|}
\hline \multirow{3}{*}{ Item } & \multirow{3}{*}{$\begin{array}{l}\text { Particulars } \\
\text { Original value }\end{array}$} & \multicolumn{4}{|c|}{ Economic parameter } \\
\hline & & $\begin{array}{l}\text { NPV (at 10\% } \\
\text { discount) rate) (₹) }\end{array}$ & $\begin{array}{l}\% \text { Increase } \\
\text { or decrease }\end{array}$ & $\operatorname{IRR}(\%)$ & $\begin{array}{l}\% \text { Increase } \\
\text { or decrease }\end{array}$ \\
\hline & & 5612161 & - & 82.86 & - \\
\hline Soil excavation & $\begin{array}{l}+20 \% \\
-20 \%\end{array}$ & $\begin{array}{l}5534944 \\
5689384\end{array}$ & $\begin{array}{l}-1.37 \\
+1.37\end{array}$ & $\begin{array}{l}77.44 \\
89.15\end{array}$ & $\begin{array}{l}-6.54 \\
+7.59\end{array}$ \\
\hline Polythene sheet & $\begin{array}{l}+20 \% \\
-20 \%\end{array}$ & $\begin{array}{l}5541444 \\
5682884\end{array}$ & $\begin{array}{l}-1.26 \\
+1.26\end{array}$ & $\begin{array}{l}77.86 \\
88.58\end{array}$ & $\begin{array}{l}-6.03 \\
+6.90\end{array}$ \\
\hline Labour charge & $\begin{array}{l}+20 \% \\
-20 \%\end{array}$ & $\begin{array}{l}5604164 \\
5620164\end{array}$ & $\begin{array}{l}-0.14 \\
+0.14\end{array}$ & $\begin{array}{l}82.26 \\
83.46\end{array}$ & $\begin{array}{l}-0.72 \\
+0.72\end{array}$ \\
\hline $\begin{array}{l}\text { Aeration facility } \\
\text { with accessories }\end{array}$ & $\begin{array}{l}+20 \% \\
-20 \%\end{array}$ & $\begin{array}{l}5592164 \\
5632164\end{array}$ & $\begin{array}{l}-0.36 \\
+0.36\end{array}$ & $\begin{array}{l}81.38 \\
84.39\end{array}$ & $\begin{array}{l}-1.79 \\
+1.85\end{array}$ \\
\hline Capital cost & $\begin{array}{l}+20 \% \\
-20 \%\end{array}$ & $\begin{array}{l}5414024 \\
5810304\end{array}$ & $\begin{array}{l}-3.53 \\
+3.53\end{array}$ & $\begin{array}{l}70.32 \\
101.42\end{array}$ & $\begin{array}{l}-15.13 \\
+22.40\end{array}$ \\
\hline Fingerlings & $\begin{array}{l}+20 \% \\
-20 \%\end{array}$ & $\begin{array}{l}5521248 \\
5703080\end{array}$ & $\begin{array}{l}-1.62 \\
+1.62\end{array}$ & $\begin{array}{l}81.83 \\
83.88\end{array}$ & $\begin{array}{l}-1.24 \\
+1.23\end{array}$ \\
\hline Feed cost & $\begin{array}{l}+20 \% \\
-20 \%\end{array}$ & $\begin{array}{l}4870774 \\
6353553\end{array}$ & $\begin{array}{l}-13.21 \\
+13.21\end{array}$ & $\begin{array}{l}74.43 \\
91.22\end{array}$ & $\begin{array}{l}-10.17 \\
+10.09\end{array}$ \\
\hline Electricity for aeration & $\begin{array}{l}+20 \% \\
-20 \%\end{array}$ & $\begin{array}{l}5476517 \\
5747811\end{array}$ & $\begin{array}{l}-2.42 \\
+2.42\end{array}$ & $\begin{array}{l}81.32 \\
84.39\end{array}$ & $\begin{array}{l}-1.86 \\
+1.85\end{array}$ \\
\hline Input cost & $\begin{array}{l}+20 \% \\
-20 \%\end{array}$ & $\begin{array}{l}4506691 \\
6717637\end{array}$ & $\begin{array}{l}-19.70 \\
+19.70\end{array}$ & $\begin{array}{l}70.26 \\
95.31\end{array}$ & $\begin{array}{l}-15.21 \\
+15.02\end{array}$ \\
\hline Production & $+20 \%$ & 8038210 & +43.23 & 110.09 & +32.86 \\
\hline & $-20 \%$ & 3186118 & -43.23 & 54.86 & -33.79 \\
\hline Sale price & $\begin{array}{l}+20 \% \\
-20 \%\end{array}$ & $\begin{array}{l}8038210 \\
3186118\end{array}$ & $\begin{array}{l}+43.23 \\
-43.23\end{array}$ & $\begin{array}{l}110.09 \\
54.86\end{array}$ & $\begin{array}{l}+32.86 \\
-33.79\end{array}$ \\
\hline
\end{tabular}


Table 5 . Sensitivity analysis of different variables with $\pm 30 \%$ variation in cost

\begin{tabular}{|c|c|c|c|c|c|}
\hline \multirow{3}{*}{ Item } & \multirow[b]{2}{*}{ Particulars } & \multicolumn{4}{|c|}{ Economic parameter } \\
\hline & & $\begin{array}{l}\text { NPV (at 10\% } \\
\text { discount rate) (₹) }\end{array}$ & $\begin{array}{l}\% \text { Increase } \\
\text { or decrease }\end{array}$ & IRR (\%) & $\begin{array}{l}\% \text { Increase } \\
\text { or decrease }\end{array}$ \\
\hline & Original value & 5612161 & - & 82.86 & - \\
\hline \multirow[t]{2}{*}{ Soil excavation } & $+30 \%$ & 5496334 & -2.06 & 75 & -9.48 \\
\hline & $-30 \%$ & 5727994 & +2.06 & 92.71 & +11.89 \\
\hline \multirow[t]{2}{*}{ Polythene sheet } & $+30 \%$ & 5506084 & -1.89 & 75.6 & -8.76 \\
\hline & $-30 \%$ & 5718244 & +1.89 & 91.78 & +10.76 \\
\hline \multirow[t]{2}{*}{ Labour charge } & $+30 \%$ & 5600164 & -0.21 & 81.96 & -1.09 \\
\hline & $-30 \%$ & 5624164 & +0.21 & 83.77 & +1.10 \\
\hline \multirow{2}{*}{$\begin{array}{l}\text { Aeration facility } \\
\text { with accessories }\end{array}$} & $+30 \%$ & 5582164 & -0.53 & 80.66 & -2.65 \\
\hline & $-30 \%$ & 5642164 & +0.53 & 85.18 & +2.80 \\
\hline \multirow[t]{2}{*}{ Capital cost } & $+30 \%$ & 5314954 & -5.29 & 65.44 & -21.02 \\
\hline & $-30 \%$ & 5909374 & +5.29 & 114.59 & +38.29 \\
\hline \multirow[t]{2}{*}{ Fingerlings } & $+30 \%$ & 5475790 & -2.43 & 81.31 & -1.87 \\
\hline & $-30 \%$ & 5748538 & +2.43 & 84.39 & +1.85 \\
\hline \multirow[t]{2}{*}{ Feed cost } & $+30 \%$ & 4500080 & -19.81 & 70.19 & -15.29 \\
\hline & $-30 \%$ & 6724248 & +19.81 & 95.38 & +15.11 \\
\hline \multirow[t]{2}{*}{ Electricity for aeration } & $+30 \%$ & 5408694 & -3.62 & 80.55 & -2.79 \\
\hline & $-30 \%$ & 5815634 & +3.62 & 85.15 & +2.76 \\
\hline \multirow[t]{2}{*}{ Input cost } & $+30 \%$ & 3953954 & -29.55 & 63.88 & -22.91 \\
\hline & $-30 \%$ & 7270374 & +29.55 & 101.5 & +22.49 \\
\hline \multirow[t]{2}{*}{ Production } & $+30 \%$ & 9251233 & +64.84 & 123.62 & +49.19 \\
\hline & $-30 \%$ & 1973095 & -64.84 & 39.95 & -51.80 \\
\hline \multirow[t]{2}{*}{ Sale price } & $+30 \%$ & 9251233 & +64.84 & 123.62 & +49.19 \\
\hline & $-30 \%$ & 1973095 & -64.84 & 39.94 & -51.80 \\
\hline
\end{tabular}

collected from local market and fish feed $35 \%$ crude protein) was prepared. The production cost of feed was $₹ 12.70 \mathrm{~kg}^{-1}$ at the market price of 2008 . If the feed containing $35 \%$ protein was purchased from the market, the cost would be more than ₹ $20 \mathrm{~kg}^{-1}$. Therefore, it is advisable that the farmers should prepare the fish feed in their own farm after undergoing some preliminary training on feed preparation. It is not necessary to prepare pelleted diet when moist feed is supplied in gunny bags. It only needs mixing of the ingredients proportionately to get the desired level of protein and the feed is supplied using the gunny bags just after steam boiling for about 10-15 min.

\section{Acknowledgements}

Authors are highly obliged to the Indian Council of Agricultural Research (ICAR), SMD Sanction No. 16-9/2004-AFC, dated 28.12.2004 for providing the necessary fund.

\section{References}

Alikunhi, K. H., Sukumaranan, K. K. and Parameswaran, S. 1971. Studies on composite fish culture: Production by composite combinations of Indian and Chinese carps. J. Indian Fish. Ass., 1(1): 26-57.

Banas, D., Masson, G., Leglize, L., Usseglio-Polatera, P. and Boyd, C. E. 2007. Assessment of sediment concentration and nutrient loads in effluents drained from extensively managed fishponds in France. Environ. Pollut., 20: 1-7.

Biswas, G., Jena, J. K., Singh, S. K. and Muduli, H. K. 2006. Effect of feeding frequency on growth, survival and feed utilisation in fingerlings of Catla catla (Hamilton), Labeo rohita (Hamilton) and Cirrhinus mrigala (Hamilton) in outdoor rearing systems. Aquac. Res., 37: 510-514.

Boyd, C. E. 2003. Guidelines for aquaculture effluent management at the farm level. Aquaculture, 226(1\&4): 101-112.

Chakrabarty, R. D., Rao, N. G. S. and Sen, P. R. 1979a. Culture of fish in ponds with fertilisation. In: Proceedings of the Seminar on Inland Aquaculture. Central Inland Fisheries Research Institute, Barrackpore, India, p. 5-6.

Chakrabarty, R. D., Sen, P. R., Rao, N. G. S. and Ghosh, S. R. 1979b. Intensive culture of Indian major carps. In: Pillay, T. V. R. and Dill, W, A. (Eds.), Advances 
in aquaculture, Fishing News Books Ltd., England, p. $153-156$.

Chaudhuri, H., Chakrabarty, R. D., Rao, N. G. S., Janikiram, K., Chatterjee, D. K. and Jena, S. 1974. Record fish production with intensive culture of Indian and exotic carps. Curr. Sci., 43(10): 303-304.

Chaudhuri, H., Chakrabarty, R. D., Sen, P. R., Rao, N. G. S. and Jena, S. 1975. A new high in fish production in India with record yields by composite fish culture in freshwater ponds. Aquaculture, 6: 343-355.

Chaudhuri, H., Rao, N. G. S., Rout, M. and Kanaujia, D. R. 1978. Record fish production through intensive fish culture. J. Inland Fish. Soc. India, 10: 19-27.

CIFA 1998. Intensive carp culture utilising biotechnological tools for achieving fish production levels of $25 \mathrm{t} \mathrm{ha}^{-1}$ annum ${ }^{-1}$. Project completion report. Central Institute of Freshwater Aquaculture, Bhubaneswar, India,115 pp.

Das, P., Kumar, D. and Guha Roy, M. K. 1975. National demonstration on composite fish culture in West Bengal. J. Inland Fish. Soc. India, 7: 112-115.

Das, P., Kumar, D., Ghosh, A. K., Chakraborty, D. P. and Bhaumik, U. 1980. High yield of Indian major carps against encountered hazards in a demonstration pond. J. Inland Fish. Soc. India, 12(1): 70-78.

Das, P., Sinha, M., Kumar, D., Chakraborty, D. P. and Guha Roy, M. K. 1977. Culture of Indian major carps with record yield in a demonstration pond. J. Inland Fish. Soc. India, 9: $105-110$.

FAO 2003. FAO yearbook of fishery statistics and aquaculture production, vol. 92/2 2001. Food and Agriculture Organisation of the United Nations, Rome, 186 pp.

Ionno, P. N. D., Wines, G. L., Jones, P. L. and Collins, R. O. 2006. A bioeconomic evaluation of a commercial scale recirculating finfish growout system - An Australian perspective. Aquaculture, 259: 315-327.

Jena, J. K. and Das, P. C. 2006. Carp culture. In: Verma, S. A., Kumar, A. T. and Pradhan, S. (Eds.), Handbook of fisheries and aquaculture. Indian Council of Agricultural Research, New Delhi, India, p. 265-282.
Jena, J. K., Ayyappan, S. and Aravindakshan, P. K. 2002a. Comparative evaluation of production performance in varied cropping patterns of carp polyculture systems. Aquaculture, 207: 49-64.

Jena, J. K., Ayyappan, S., Aravindakshan, P. K., Dash, B., Singh, S. K. and Muduli, H. K. 2002b. Evaluation of production performance in carp polyculture with different stocking densities and species combinations. J. Appl. Ichthyol., 18: $165-171$

Jhingran, V. G. 1991. Fish and fisheries of India. Hindustan Publ. Corporation, Delhi, India, 727 pp.

Lakshmanan, M. A. V., Sukumaranan, K. K., Murty, D. S., Chakraborty, D. P. and Philipose, M. T. 1971. Preliminary observations on intensive fish farming in freshwater ponds by the composite culture of Indian and exotic species. J. Inland Fish. Soc. India, 3: 1-21.

Larson, K. D., Wild, J. J. and Chiappetta, B. 2002. Fundamental accounting principles, $16^{\text {th }}$ edn. McGraw-Hill Irwin Publishing, USA.

Nandeesha, M. C., Gangadhara, B., Manissery, J. K. and Venkataraman, L. V. 2001. Growth performance of two Indian major carps catla (Catla catla) and rohu (Labeo rohita) fed diets containing different levels of Spirulina platensis. Bioresour. Technol., 80: 117-120.

Petty, J. W., Peacock, R., Martin, P., Burrow, M., Keown, A. J., Scott, D. F. and Martin, J. D. 1996. Basic financial management. Prentice Hall Publishing, Sydney, Australia.

Reddy, P. V. G. K., Gjerde, B., Tripathi, S. D., Jana, R. K., Mahapatra, K. D., Gupta, S. D., Saha, J. N., Sahoo, M., Lenka, S., Govindassamy, P., Rye, M. and Gjedrem, T. 2002. Growth and survival of six stocks of rohu (Labeo rohita, Hamilton) in mono and polyculture production systems. Aquaculture, 203: 239-250.

Sugiura, S. H., Marchant, D. D., Kelsey, K., Wiggins, T. and Ferraris, R. 2006. Effluent profile of commercially used low-phosphorus fish feeds. Environ. Pollut., 140: $95-101$

Tripathi, S. D., Aravindakshan, P. K., Ayyappan, S., Jena, J. K., Muduli, H. K., Suresh, C. and Pani, K. C. 2000. New high in carp production in India through intensive polyculture. J. Aquac. Trop., 15: 119-128. 